\title{
Publisher Correction: Endothelial progeria induces adipose tissue senescence and impairs insulin sensitivity through senescence associated secretory phenotype
}

\author{
Agian Jeffilano Barinda (10, Koji Ikeda, Dhite Bayu Nugroho (D), Donytra Arby Wardhana, Naoto Sasaki, \\ Sakiko Honda, Ryota Urata, Satoaki Matoba, Ken-ichi Hirata \& Noriaki Emoto
}

Correction to: Nature Communications https://doi.org/10.1038/s41467-020-14387-w, published online 24 January 2020.

This article contained errors in Fig. 1a and Fig. 3d. In the original version of Fig.1a, the wrong image was chosen, showing SA- $\beta$-Gal staining in 3T3-L1 adipocytes treated with conditioned medium derived from young endothelial cells (ECs) transfected with GFP. This has now been replaced with the correct image, showing SA- $\beta$-Gal staining in 3T3-L1 adipocytes treated with conditioned medium derived from young untransfected ECs. In the original version of Fig. 3d, the bottom left panel, reporting SA- $\beta$-Gal staining in 3T3-L1 adipocytes treated with the conditioned medium derived from premature senescent ECs (EC/TERF2DN) in the presence of $\beta N M N$, was inadvertently duplicated from the top left pane. This panel has now been replaced with the correct image. These errors have now been corrected in both the PDF and HTML versions of the article.

Published online: 28 July 2020

Open Access This article is licensed under a Creative Commons Attribution 4.0 International License, which permits use, sharing, adaptation, distribution and reproduction in any medium or format, as long as you give appropriate credit to the original author(s) and the source, provide a link to the Creative Commons license, and indicate if changes were made. The images or other third party material in this article are included in the article's Creative Commons license, unless indicated otherwise in a credit line to the material. If material is not included in the article's Creative Commons license and your intended use is not permitted by statutory regulation or exceeds the permitted use, you will need to obtain permission directly from the copyright holder. To view a copy of this license, visit http://creativecommons.org/licenses/by/4.0/.

(C) The Author(s) 2020 